\title{
THE RISK OF ARSENIC CONTAMINATION IN CZECH URBAN SOILS
}

\author{
Magdalena ZIMOVÁ ${ }^{1}$, Zdeňka WITTLINGEROVÁ ${ }^{2}$, Jan MELICHERČÍK ${ }^{3}$, \\ Anita ZÁVODSKÁ ${ }^{4}$, Anna CIDLINOVÁ ${ }^{5}$, Vladimíra NĚMCOVÁ ${ }^{6}$ and Pavel DANIHELKA ${ }^{7}$
}

Research article

Abstract: $\quad$ Arsenic (As) contamination was investigated in urban soil agglomerates in the Czech
Republic. The aim of studying surface urban soil layers was to assess the degree of health
risk resulting from the exposure to toxic substances through unintended consumption
of soil and soil dust. Given that the greatest risk of increased exposure is for the
population of preschool-aged children, the project focused on kindergarten playgrounds.
Measurements were carried out in a total of 413 kindergartens in 38 towns between 2002
and 2007 . Selected metals and polycyclic aromatic hydrocarbons were monitored in the
surface soil layer samples of the playgrounds. This study presents the results of the soil
As contamination and evaluates the health risks faced by children through exposure to
these soils. Based on the results of the soil analysis and on the use of residential exposure
scenarios for preschool-aged children, the oral and dermal exposures to As in children
within the 1 to 6 year age group were estimated. At all monitored sites the risk was found
to be higher than $1 \times 10^{-6}$. When the overall risk of cumulative exposure to As during
childhood and adulthood was evaluated, the risk of $1 \times 10^{-6}$ was exceeded in about $99 \%$ of
the cases and the risk of $1 \times 10^{-5}$ was exceeded in about $54 \%$ of the cases.
Soil, Arsenic, Health risk evaluation, Czech Republic, Children, Playgrounds.

\section{Introduction}

According to previous investigation (Beneš et Fabiánová, 1986), the average concentration of As in Czech agricultural soils ranges from 1.8 to $18.4 \mathrm{mg} \cdot \mathrm{kg}^{-1}$. Apart from mining and industrial activities, a very important source of As are dust and ash that are produced from the burning of brown coal in thermal power stations and local furnaces which may subsequently increase As levels to hundreds of mg.kg-1 (Bencko et al., 1995). Contaminated soil may be an important source of human exposure to As, especially with unintentional ingestion of soil and soil dust.

Concentrations of As were monitored from 2002 to 2007 in samples of surface soil at kindergarten playgrounds in selected towns in the Czech Republic. Monitoring the soil in urban agglomerations is a part of the Czech system of monitoring population health as it relates to the environment. The monitoring focused on the assessment of health risks for oral and dermal exposure to As from urban soils (Zimová et al., 2007; Zimová et al., 2008). An increased exposure to harmful elements from contaminated soil as well as potential health risk for young preschool-aged children aged 1 to 6 years have been demonstrated (Calabrese et Stanek, 1994; Calabrese et al., 1997; Paustenbach, 2000; Weaver et al., 1998). The authors noted a higher exposure to metals in small children as a result of unintended ingestion of soil particles when a) playing on outdoor playgrounds, b) licking their fingers, hands and various objects such as toys, and c) eating soil. According to some authors (Armstrong et al., 2000), exposure of children to toxic elements from the soil is many times higher than similar exposure for adults.

Czech University of Life Sciences, Faculty of Environmental Sciences, Prague, Czech Republic, mzimova@szu.cz

2 Czech University of Life Sciences, Faculty of Environmental Sciences, Prague, Czech Republic

3 National Public Health Institute, Prague, Czech Republic

4 School of Adult and Continuing Education, Barry University, Davie, Florida, USA

5 Czech University of Life Sciences, Faculty of Environmental Sciences, Prague, Czech Republic

6 Institute of Public Health in Ostrava, Center of Hygienic Laboratories, Ostrava, Czech Republic

7 VSB - Technical University of Ostrava, Faculty of Safety Engineering, Ostrava, Czech Republic 


\section{Materials and methods}

Evaluation of the health risks from As exposure in kindergarten playground soil included the following steps: sampling and chemically analyzing the soil samples, selecting the exposure model, and calculating the exposure and characterizing the health risk.

\section{Sampling and Chemical analysis}

During the 2002 - 2007 period soil sampling was carried out at the playgrounds of 413 kindergartens in 38 towns in the Czech Republic. Surface soil samples were collected and processed according to Standard Operating Procedures that had been developed within the framework of the study. The soil samples were collected down to a depth of $10 \mathrm{~cm}$ from five sampling sites at each outdoor playground. The sampling sites were selected taking into account the most frequent locations of the children's stay on the playground. After removal of extraneous material (e.g. stones, glass fragments, roots, etc.), all five samples were homogenized in a plastic container of adequate size. Contents of the container were emptied onto a PE sheet and then a circle (pie) was created with a thickness of $1-2 \mathrm{~cm}$, which was subsequently divided into four quadrants. Two opposite quadrants were amalgamated (the other two were removed) in a clean PE container and re-homogenized. By additional quartering the sample mass was reduced to $1 \mathrm{~kg}$. The resulting sample was taken to an accredited laboratory for analysis. Determination of As in the soil sample was performed by a hybrid technique using X-ray spectrometry with secondary emission and an energy dispersive semiconductor detector.

\section{Exposure model}

To assess the health risks in children exposed to As in playground soil, a residential exposure scenario for ingestion of soil and soil dust, and for the dermal contact with the soil were selected in accordance with previously established methodologies (EPA, 1997; EPA, 1999; EPA, 2001; EPA, 2004; EPA, 2005). Deterministic and probabilistic methods were used for the health risk assessment. Due to a relatively regular distribution of the kindergartens across the areas of the monitored towns, it was assumed that the level of contamination of surface soils in the urban agglomerates was homogeneous and corresponded to a set of identified values. In assessing the risk of cancer, it was also assumed that the concentration of As in the soil for the duration of exposure was constant.

\section{Parameter values and calculation of the exposure}

Oral exposure - the average daily non-carcinogenic oral dose of As $\left(\mathrm{CDI}_{\mathrm{n}}\right)$ for ingestion of soil and soil dust was calculated according to as follows: $\mathrm{CDI}_{\mathrm{n}}\left[\mathrm{mg} \cdot \mathrm{kg}^{-1}\right.$. day $\left.^{-1}\right]=(\mathrm{CS} \times \mathrm{CF} \times \mathrm{EF} \times \mathrm{B} \times \mathrm{IR} \times \mathrm{ED}) /(\mathrm{BW} \times \mathrm{AT})$ The average daily carcinogenic oral dose of As (CDI) for ingestion of soil and soil dust was calculated as follows: CDI $\left[\mathrm{mg}_{\mathrm{c}} \mathrm{kg}^{-1}\right.$.day $\left.{ }^{-1}\right]=(\mathrm{CS} \times \mathrm{EF}) / \mathrm{AT} x\left[\left(\mathrm{ED}_{\mathrm{c}}\right.\right.$ $\left.\left.\left.\mathrm{x}\left(\mathrm{IR}_{\mathrm{c}}\right) / \mathrm{BW}_{\mathrm{c}}\right)+\left(\mathrm{ED}_{\mathrm{a}} \mathrm{x} \mathrm{IR}_{\mathrm{a}}\right) / \mathrm{BW}_{\mathrm{a}}\right)\right]$. The values of the parameters used for the calculation of the daily oral non-carcinogenic and carcinogenic doses of As from the contaminated soil were determined from a literary background (Ministry of the Environment, 2005; EPA, 1991; EPA, 1997; EPA, 2004).

Dermal exposure - the average daily dermal non-carcinogenic doses of As and the daily dermal carcinogenic doses of As for the dermal contact with the soil were determined as follows: $\mathrm{CDI}_{d}$ $\left[\mathrm{mg} \cdot \mathrm{kg}^{-1} \cdot \mathrm{day}^{-1}\right]=(\mathrm{CS} \times \mathrm{FI} \times \mathrm{AF} . \mathrm{ABS} \times \mathrm{SA} \times \mathrm{ED} \times$ $\mathrm{EF}) /(\mathrm{BW} \times \mathrm{AT})$. The values of the parameters used for the calculation of the dermal non-carcinogenic and carcinogenic doses of As from the contaminated soil were determined from a literary background (EPA, 2004).

\section{Characterization of the risk - the deterministic method of evaluation of the health risk}

The level of non-carcinogenic risk is expressed as a coefficient of hazard (hazard index - HI). It is calculated as: $\mathrm{HI}=\mathrm{CDI}_{\mathrm{n}} / \mathrm{RfD}$ where $\mathrm{RfD}$ is the reference dose measured in $\mathrm{mg}^{\mathrm{n}} \mathrm{kg}^{-1}$. day ${ }^{-1}$. The threshold value equals 1 . To calculate the oral exposure to As, an RfD of 0.0003 mg. $\mathrm{kg}^{-1}$. day ${ }^{-1}$ was used and for the dermal exposure, an RfD value of $0.000123 \mathrm{mg} \cdot \mathrm{kg}^{-1}$.day ${ }^{-1}$ was used. An overall risk of toxicity was expressed by the sum of the values of the risk of oral and dermal exposures (EPA, 2005). The rate of individual lifelong cancer risk is expressed by: ILCR $=\mathrm{CDI}_{\mathrm{c}} \cdot \mathrm{CSF}$, where ILCR is an individual lifetime cancer risk. $\mathrm{CDI}_{c}$, measured in $\mathrm{mg} \cdot \mathrm{kg}^{-1}$. day ${ }^{-1}$, is the average daily carcinogenic dose and CSF, measured in mg. $\mathrm{kg}^{-1}$. day ${ }^{-1}$, is a risk of cancer indication (cancer slope factor). The value of CSF for oral exposure to As is $1.5 \mathrm{mg} . \mathrm{kg}^{-1}$. day ${ }^{-1}$ and for the dermal exposure to As is $3.66 \mathrm{mg} \cdot \mathrm{kg}^{-1}$. day ${ }^{-1}$. An overall risk of cancer from exposure to As from soil is determined by the sum of the values of risks arising from oral and dermal exposures (EPA, 2005). The threshold value of ILCR ranged from $1 \times 10^{-4}$ to $1 \times 10^{-6}$ depending on the size of the study subjects. 


\section{Results}

\section{Concentration of As in soils}

The chemical analyses of the soil samples from the monitored kindergarten playgrounds showed the lowest concentration of As in the soil in České Budějovice at $0.3 \mathrm{mg} \cdot \mathrm{kg}^{-1}$. The concentration of As in the soil of the city ranged from 0.3 to $27.3 \mathrm{mg} \cdot \mathrm{kg}^{-1}$. The highest concentration was measured in the town of Ostrov in the Karlovy Vary Region with a value of $414 \mathrm{mg} \cdot \mathrm{kg}^{-1}$. The concentration of As in the soil here ranged from $6.63 \mathrm{mg} \cdot \mathrm{kg}^{-1}$ to $414 \mathrm{mg} \cdot \mathrm{kg}^{-1}$. The value of $10 \mathrm{mg} \cdot \mathrm{kg}^{-1}$ of As in the soil, which is the limit recommended by the Ministry of Health, was exceeded in a total of 175 cases, representing $49 \%$ of the total number of monitored kindergartens.

\section{Chronic daily intake and lifetime average daily intake}

The oral exposure pathway represents an important exposure to As. Intake via the oral exposure pathway is about ten times greater than via the dermal exposure pathway. With a chronic daily oral intake of $3 \times 10^{-4} \mathrm{mg} \cdot \mathrm{kg}^{-1}$. day ${ }^{-1}$ an increased health risk can be noted. This value was exceeded at four localities (median estimate): Teplice, Benešov, Príbram and the Karlovy Vary region. In the Karlovy Vary region it was exceeded twofold. For the upper estimate of exposure, the reference dose $\left(1.23 \times 10^{-4} \mathrm{mg} \cdot \mathrm{kg}^{-1} \cdot\right.$ day $\left.^{-1}\right)$ was exceeded six times altogether (in Plzen̆, Liberec, Teplice, Benešov, Př́bram and the Karlovy Vary region). The elevated levels of daily doses are directly related to the measured As concentrations in the soil of the listed towns.

After adding up the values for both exposure pathways, the highest chronic daily intake occurred in the Karlovy Vary region: $5.84 \times 10^{-4} \mathrm{mg} \cdot \mathrm{kg}^{-1}$. day ${ }^{-1}$ (median estimate) and $1.61 \times 10^{-4} \mathrm{mg} \cdot \mathrm{kg}^{-1}$.day ${ }^{-1}$ (upper estimate). The lowest chronic daily intake was measured in Šumperk: $9.05 \times 10^{-5} \mathrm{mg} \cdot \mathrm{kg}^{-1} \cdot \mathrm{day}^{-1}$ (median estimate) or $1.40 \times 10^{-4} \mathrm{mg} \cdot \mathrm{kg}^{-1}$.day ${ }^{-1}$ (upper estimate) and in Olomouc: $9.14 \times 10^{-5} \mathrm{mg} \cdot \mathrm{kg}^{-1}$. day ${ }^{-1}$ (median estimate) or $1.36 \times 10^{-4} \mathrm{mg} \cdot \mathrm{kg}^{-1} \cdot \mathrm{day}^{-1}$ (upper estimate). The values for the dermal exposure are about 10 times lower than for the oral exposure. The lowest overall exposure was $7.76 \times 10^{-6} \mathrm{mg} \cdot \mathrm{kg}^{-1}$.day ${ }^{-1}$ (median estimate) or $1.19 \times 10^{-5} \mathrm{mg} \cdot \mathrm{kg}^{-1} \cdot \mathrm{day}^{-1}$ (upper estimate) in Šumperk and the highest overall exposure was $5.01 \times 10^{-5} \mathrm{mg} \cdot \mathrm{kg}^{-1}$.day ${ }^{-1}$ (median estimate) or $1.36 \times 10^{-4} \mathrm{mg} \cdot \mathrm{kg}^{-1}$.day ${ }^{-1}$ (upper estimate) in the Karlovy Vary region.
Fig. 1 shows the values of central and upper estimates of the lifetime average daily intake of As (LADD, or more precisely CDIc) calculated for oral exposure pathway of the children in individual towns. Fig. 2 shows the values of central and upper estimates of the lifetime average daily intake (LADD) of As calculated for dermal exposure pathway of the children in individual towns.



Fig. 1 Oral exposure to arsenic in children expressed as an average lifetime daily intake LADDo $\left[\mathrm{mg} \cdot \mathrm{kg}^{-1} \cdot \mathrm{day}^{-1}\right]$

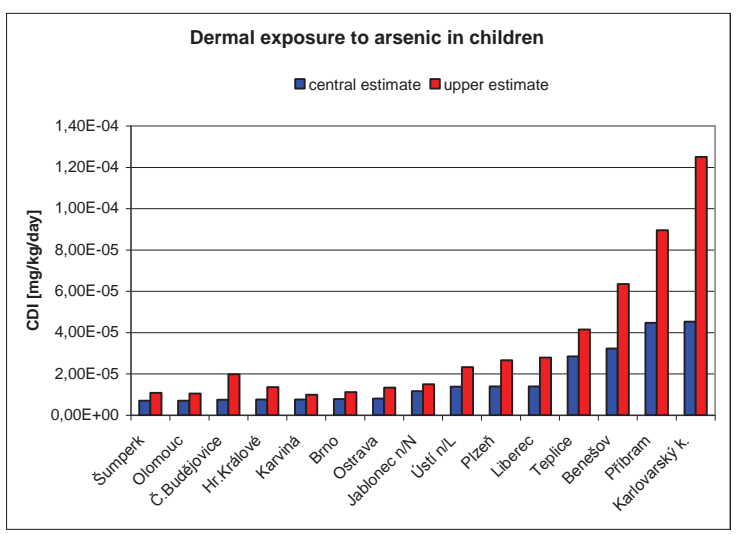

Fig. 2 Dermal exposure to arsenic in children expressed as an average lifetime daily intake LADDd [mg. $\left.\mathrm{kg}^{-1} \cdot \mathrm{day}^{-1}\right]$

\section{Hazard index (HI)}

The results of the evaluation of the toxic (non-carcinogenic) health risks have confirmed the ingestion of soil as the more important exposure pathway. The level of the toxicity risk expressed by means of HI is limited by the value of 1 . This value was exceeded for the oral exposure in Teplice, Benešov, Př́bram and the Karlovy Vary region with respect to the median estimates, and in Plzeň, Liberec, as well as the four afore-mentioned towns, with respect to the upper estimates. 


\section{Risk of cancer occurrence (Individual Lifetime Cancer Risk)}

For oral exposure to As, the median estimate of Individual Lifetime Cancer Risk (ILCR) exceeds $1 \times 10^{-5}$, the commonly accepted level of cancer risk used for the evaluation of carcinogenesis incidence at the local level. For dermal exposure to As, the level of acceptable risk has been exceeded in three towns (median estimate) or four towns (upper estimate). In the Karlovy Vary region, the total exposure exceeded the level of acceptable risk more than eight-fold and in the case of the upper estimate as much as twenty-fold.

The median estimate for the exposure in children in both the oral and dermal exposure pathways exceeded $1 \times 10^{-6}$, the acceptable level of cancer risk used for the evaluation of carcinogenesis incidence at the regional level. In children, it was shown that the cancer risk level for the oral exposure pathway was about five times higher than for the dermal exposure pathway. The total direct exposure of children to As from urban soil indicates a possible cancer risk at $1.87 \times 10^{-5}$ (median estimate) and $6.31 \times 10^{-5}$ (upper estimate). In the adult population, this risk is about three times lower when exceeding the acceptable level of $1 \times 10^{-6}$. When evaluating the cumulative risk from soil As exposure in childhood and in adulthood, the ILCR value equals $2.40 \times 10^{-5}$ (median estimate) and $8.09 \times 10^{-5}$ (upper estimate).

\section{Analysis of sensitivity}

Fig. 3 illustrates the results of the sensitivity analysis for the calculation of the toxicity risk and the risk of tumor diseases from total exposure to As in urban soils in children and adults. The most important variables from the view of the risk calculation are ranked according to the size of relative contributions to the variance of the final value of the risk. In terms of the calculation of the toxicity risk and the risk of carcinogenicity, the individual contributions do not differ from each other significantly.

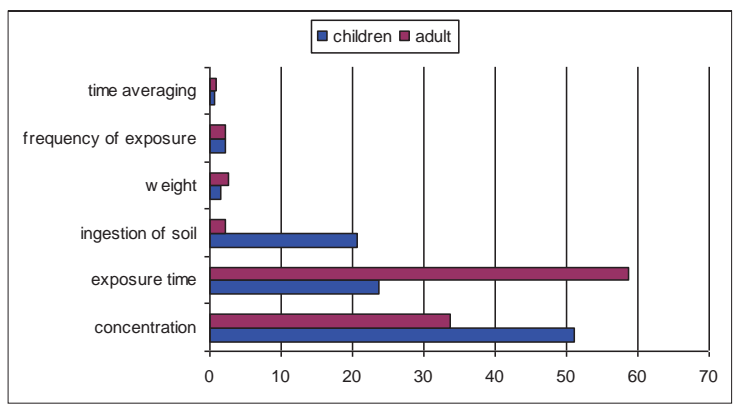

Fig. 3 Analysis of sensitivity for the risk estimate of the total As exposure in urban soils to children and adults [\%]
It is clear that the key variables for the calculations of toxicity and carcinogenicity in children and adults are the As concentrations in the soil and the duration of exposure. The significance of the effect of As concentration in the soil for children is associated with a higher intensity in the contact with the soil (a higher intake by means of ingestion and dermal contact). The exposure in adults can be explained by a much longer duration of exposure which is four times longer than in children. According to the probabilistic assignment the quantity of ingested earth in children ranges from 5 to

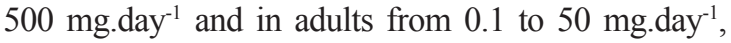
which is a tenfold difference between the children and adults, respectively. The other, considerably less significant variables, do not exceed the limit of a $3 \%$ relative contribution.

\section{Discussion}

Given that As is a proven human carcinogen it is not possible, due to its thresholdless action, to determine a safe exposure concentration or exposure limit. It is only possible to provide a socially acceptable threshold level of health risk (Provazník et al., 2000). Children's playgrounds in the Czech Republic have a prescribed hygienic limit for soil As levels of $10 \mathrm{mg} \cdot \mathrm{kg}^{-1}$ in dry matter (Ministry of the Environment, 2005). That limit has been exceeded in many parts of the Czech Republic, mostly in the Karlovy Vary region, Teplice, Př́bram and Benešov. The higher concentrations identified may have been caused by residues of mining activities. In the Czech Republic there are many brown coal seams that can contain up to $1.5 \mathrm{~g}$ of As per $1 \mathrm{~kg}$ of coal. In the Karlovy Vary region, and also around Teplice, there are, according to (Integrated Pollution Register, 2009), brown coal thermal power stations, the emissions of which contain As in the form of condensed $\mathrm{As}_{2} \mathrm{O}_{3}$ that forms a coating of fine light ash particles on chimneys. Another source of As in the Czech Republic is home heating that requires the burning of As-containing brown coal which is an example of small local pollution sources. Contamination of the soil is then caused by a high number of small local sources in a given region. Past mining of rare metals in the neighborhoods of the towns of Príbram and Benešov are now also affected by the so-called "old ballast." Arsenic used to escape into the environment even during mining operations and following weathering of mineral material and was thus able to contaminate soil, water and the biosphere (Skrrivan, 1996). However, our results indicate that the As-contaminated soil is a greater health risk compared to the risk of eating As-contaminated seafood. The risk observed in children and adults was significantly below the value of 104 (Chen et al., 2010). 
Data from studies involving trace elements support the preliminary estimate of the average ingestion of dirt by children most frequently as being within the range of 100 - $200 \mathrm{mg}$.day ${ }^{-1}$. The maximum upper values for children eating dirt are estimated at around

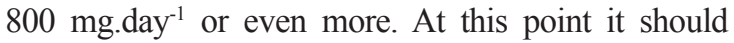
be noted that these studies had worked with limited samples of persons, and that none of them was focused specifically on children with geophagy. Unintended ingestion of soil occurs in both children and adults. Since the actual measurements of the soil ingestion by adults have not yet been implemented (Hawley, 1985), estimates of $61 \mathrm{mg} . d a y^{-1}$ seem appropriate. This is based on unverified assumptions regarding the patterns of activities and related quantities of ingested dirt (Skřivan, 1996). The authors (Calabrese

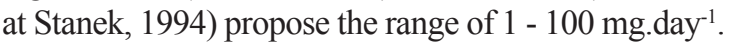
The greatest problem in the selection and assignment of exposure parameters is the non-existence of the database of key parameters for the Czech population. Most of the data used for the creation of parameters come from abroad. If there were such a database, the selected parameters could have been adapted to the conditions of the Czech Republic and the results would have had greater accuracy and informative value.

We include the bioavailability of the As bound to soil particles in the digestive tract amongst the important parameters which have not been assigned probabilistic functions. According to some ( $\mathrm{Ng}$ et al., 2009) the bioavailability of As in the gastrointestinal tract ranges from $28 \%$ to $92 \%$. The U.S. EPA (1996) indicates the values of $42 \%-78 \%$. Apart from the physico-chemical properties of the contaminant and the characteristics of the appropriate matrix, the bioavailability of As in the dermal contact is also affected by the size of exposed areas of skin, skin diffusivity, the length of contact and the adhesivity of the matrix to the skin (EPA, 2004). The dermal bioavailability factor for As is given a value of 0.03 .

Important are the parameters that are specific to the dermal exposure, indices of carcinogenic risk and the reference doses. Disregard for the parameters of dermal exposure has most likely resulted in an increase in the results of estimating the exposure through dermal contact in adults.

In terms of acceptable risk, the target range of risk from $1 \times 10^{-6}$ to $1 \times 10^{-4}$ is usually used due to uncertainties associated with estimating the risks from exposure to carcinogens in the environment. It should also be pointed out that the acquired risk estimates contain certain conservatism, which is mainly due to assuming a $100 \%$ biological effectiveness of the As absorption in the digestive tract and assuming a constant concentration of As in the soil for the entire length of the reference period of exposure (European Commision, 2009). The results of the completed sensitivity analysis confirm the importance of regular monitoring of the polluted urban environment and obtaining accurate and timely information about the soil contamination such as origin and age. Obtaining more information on the bioavailability of As bound to soil particles in the human gastrointestinal tract would also reduce the uncertainty in the final risk estimate. A lack of data on the spread of geophagy and the pica behavior in the Czech Republic (Šmerhovský et al., 2006) is also a major deficiency in the exposure assessment of the soil contamination of small children.

\section{Conclusion}

The results of the study have confirmed the relevance of the health risks from exposure to As in Czech urban soil agglomerates. The calculations have confirmed that the level of the As exposure with carcinogenic properties has been exceeded, particularly in the population of children.

The obtained results also show significant differences in the extent of exposure in children and adults. Although the children are, within the framework of the selected residential scenarios, subjected to As exposure from contaminated soil for a considerably shorter time, their health risk of tumor diseases was six times higher compared to the adult population. This confirms the higher sensitivity of the population of children and the importance of preventive measures that would lead towards a decreased exposure for this group.

The calculations have not determined increased health risks in terms of non-carcinogenic effects (HI) of As for children in any of the studied exposure pathways at any of the monitored sites. In the evaluation of the cancer risks (ILCR) of the total exposure to carcinogenic As, a risk greater than $1 \times 10^{-5}$ was found at 8 monitored sites at which even the As limit concentration in the soil had been exceeded.

A risk higher than $1 \times 10^{-6}$ was found at all sites. When the risk of the total exposure to the carcinogenic As within the framework of the whole country is evaluated, the acceptable level of risk at $1 \times 10^{-6}$ is exceeded in $99 \%$ of the population of children and in $64 \%$ of the adult population. A risk exceeding $1 \times 10^{-5}$ was found in $47 \%$ of the population of children and in $4 \%$ of the adult population. When the risk of cumulative As exposure during childhood and adulthood is evaluated, the risk of $1 \times 10^{-6}$ is exceeded in approximately $99 \%$ of the monitored population and the risk of $1 \times 10^{-5}$ is exceeded in approximately $54 \%$ of the monitored population. 


\section{References}

ARMSTRONG, T.W., HUSHKA, L.J., TELL, J.G., ZALESKI, R.T. (2000). A Tiered Approach for Assessing Children's Exposure, Environmental Health Perspectives 108 (2000) 469-474.

BENCKO, V., CIKRT, M., LENER, J. (1995). Toxické kovy v pracovním a životním prostředí člověka. Grada Aviceum, Praha 1995.

BENEŠ, S., FABIÁNOVÁ, J. (1986). Přirozené obsahy, distribuce a klasifikace prvků v půdách. VŠZ, Praha 1986.

CALABRESE, E.J., STANEK, E.J. (1994). Soil ingestion issues and recommendations. Journal Environmental Science Health 29 (1994) 517-530.

CALABRESE, E.J., STANEK, E.J., JAMES, R.C., ROBERTS, S.M. (1997). Soil ingestion: a concern for acute toxicity in children. Environmental Heatlh Perspectives 105 (1997) 1354-1358.

CHEN, B.C., CHOU, W.C., CHEN, W.Y., LIAO, C.M. (2010). Assessing the cancer risk associated with arseniccontaminated seafood. Journal of Hazardous Materials 4 (2010).

EUROPEAN COMMISION (2009). Technical Guidance Document in support of Commission Directive 93/67/ EEC on Risk Assessment for new notified substances, Commision Regulation (EC) No 1488/94 on Risk Assessment for existing substances and Directive 98/8/EC of the European Parliament and of the Council concerning the placing of biocidal products on the market (2009). Available at: $<$ http://ecb.jrc.it/tgdoc $>$.

HAWLEY, J.K. (1985). Assessment of health risk from exposure to contaminated soil. Risk Analysis 5 (1985) 289-302.

INTEGROVANÝ REGISTR ZNEČIŠŤOVÁNÍ (2009). Available at: <http://www.irz.cz/>.

Ministerstvo životního prostředí (2005), Metodický pokyn pro analýzu rizik kontaminovaného území, Věstník MŽP, ročník 15, 2005.

NG, J.C., NOLLER, B., BRUCE, S., MOORE, M.R. (2009). Bioavailability of metals and arsenic at contaminated sites from cattle dips, mined land and naturally occurring mineralisation origins. Fifth National Workshop on the Assessment of Site Contamination (2009). Available at: <http://www.ephc.gov.au>.

PAUSTENBACH, D.J. (2000). The practise of exposure assessment: a state of the art review. Journal of Toxicology and Environmental Health Part B: Critical Reviews 3 (2000) 179-291.

PROVAZNÍK, K., CIKRT, M., KOMÁREK, L. (2000). Manuál prevence v lékařské praxi VIII: Základy hodnocení zdravotních rizik, Fortuna Praha 2000.

SKŘIVAN, P. (1996). Koloběh arzenu v přírodním prostředí. Vesmír 75 (1996) 247-248.

ŠMERHOVSKÝ, Z., LANDA, K., VAVŘINOVÁ, J. (2006). Systém monitorování zdravotního stavu obyvatelstva České republiky ve vztahu k životnímu prostředí: Souhrnná zpráva za rok 2005. SZŮ Praha 2006.

U.S. EPA (1991). Risk Assessment Guidance for Superfund: Volume I - Human Health Evaluation Manual (Part B, Development of Risk-based Preliminary Remediation Goals). Office of Emergency and Remedial Response, U.S. Environmental Protection Agency, Washington, DC (1991). Available at: < http://www.epa.gov>.

U.S. EPA (1996). Soil Screening Guidance. Technical Background Document. EPA/540/R-96/018. U.S. Environmental Protection Agency, Washington, DC (1996). Available at: <http://www.epa.gov>.

U.S. EPA (1997). Exposure Factors Handbook. Volume I - General factors. Office of Research and Development National. Center for Environmental Assessment. EPA/600/P-95/002Fa (1997). Available at: <http://www.epa.gov>.

U.S. EPA (1997). Guiding Principles for Monte Carlo Analysis. Office of Research and Development, EPA/630/R-97/001 (1997). Available at: <http://www.epa.gov>.

U.S. EPA (1999). Guidance for Conducting Risk Assessments and Related Risk Activities for the DOE-ORO Environmental Management Program. Prepared by The University of Tennessee, Knoxville, Tennessee for U.S. Department of Energy Office of Environmental Management under subcontract 11K-FYT71C. Appendix F. Program BJC/OR-271 (1999). Available at: <http://rais.ornl.gov>.

U.S. EPA (2001). Risk Assessment Guidance for Superfund: Volume III - Part A, Process for Conducting Probabilistic Risk Assessment. Office of Emergency and Remedial Response Washington. EPA/540/R-02/002 (2001). Available at: <http://www.epa.gov>.

U.S. EPA (2004). Risk Assessment Guidance for Superfund Volume I: Human Health Evaluation Manual (Part E, Supplemental Guidance for Dermal Risk Assessment). Final version. EPA/540/R/99/005 (2004). Available at: $<$ http://www.epa.gov>. 
U.S. EPA (2005). Risk-Based Concentration Table (2005). Available at: <http://www.epa.gov>.

WEAVER, V.M., BUCKLEY, T.J., GROOPMAN, J.D. (1998). Approaches to environmantal exposure assessment in children. Environmental Health Perspect 106 (1998) 827-832.

ZIMOVÁ, M., MELICHERČÍK, J., BÍBROVÁ, Z., PODOLSKÁ, Z., VEDRALOVÁ, E., JEŽOVÁ, M. (2006). Zdravotní rizika kontaminace půdy městských aglomerací. Odborná zpráva za rok 2006. Systém monitorování zdravotního stavu obyvatelstva ve vztahu k životnímu prostředí. SZÚ Praha 2007.

ZIMOVÁ, M., MELICHERČÍK, J., PODOLSKÁ, Z., VEDRALOVÁ, E., VENCÁLEK, E., JEŽOVÁ, M. (2008). Zdravotní rizika kontaminace půdy městských aglomerací. Odborná zpráva za rok 2007. Systém monitorování zdravotního stavu obyvatelstva ve vztahu k životnímu prostředí. SZÚ Praha 2008. 